Pacific Journal of Mathematics

NOTE ON A PAPER OF LG GUM 


\section{A NOTE ON A PAPER OF L. GUTTMAN}

\section{A. C. Mewborn}

In a recent paper L. Guttman [2] obtained, using a result of von Neumann on the theory of games, lower bounds for the largest characteristic root of the matrix $A A^{\prime}$ where $A$ is a real matrix of order $m \times n$. As Guttman points out his bounds are non-trivial only if some row or column of $A$ has only positive or only negative elements. I wish to show that Guttman's results, and even a better result, are an immediate corollary of a well known theorem on Hermitian matrices: that each diagonal element lies between the smallest and largest characteristic roots (see e.g. [1]). Moreover, if $A A^{\prime}$ be replaced by $A A^{*}$ then $A$ can be real or complex and a non-trivial result is always obtained.

THEOREM 1. Let $A=\left(a_{i j}\right)$ be an $m \times n$ matrix with real or complex elements. Let $\lambda$ be the largest characteristic root of the $m \times m$ nonnegative definite Hermitian matrix $B=A A^{*}=\left(b_{i j}\right)$. Then

$$
\begin{aligned}
& \lambda \geqq \max _{i} \sum_{j=1}^{n}\left|a_{i j}\right|^{2} \\
& \lambda \geqq \max _{j} \sum_{i=1}^{m}\left|a_{i j}\right|^{2}
\end{aligned}
$$

Proof. Let $b_{r r}$ be the largest diagonal element of $B$. Then

$$
\lambda \geqq b_{r r}=\sum_{j=1}^{n}\left|a_{r j}\right|^{2}=\max _{i} \sum_{j=1}^{n}\left|a_{i j}\right|^{2},
$$

and (1) is proved. Now the non-zero characteristic roots of $A A^{*}$ are the same as those of $A^{*} A$. Then (2) follows as above if we consider $A^{*} A$ instead of $A A^{*}$.

The bounds in (1) and (2) can be replaced by the weaker bounds

$$
\begin{aligned}
& \lambda \geqq n \cdot \max _{i}\left(\min _{j}\left|a_{i \jmath}\right|^{2}\right) \\
& \lambda \geqq m \cdot \max _{j}\left(\min _{i}\left|a_{i j}\right|^{2}\right)
\end{aligned}
$$

respectively, and even these bounds are obviously better than Guttman's.

Theorem 1 can be improved further.

\section{THEOREM 2. Under the hypotheses of Theorem 1 we have}

Received October 25, 1957. The author is a National Science Foundation fellow. 
(5) $\quad 2 \lambda \geqq \max _{i, j}\left[\sum_{\nu=1}^{n}\left(\left|a_{i \nu}\right|^{2}+\left|a_{j \nu}\right|^{2}\right)+\left\{\left[\sum_{\nu=1}^{n}\left(\left|a_{i \nu}\right|^{2}-\left|a_{j \nu}\right|^{2}\right)\right]^{2}+4\left|\sum_{\nu=1}^{n} a_{i \nu} \bar{a}_{j \nu}\right|^{2}\right\}^{1 / 2}\right]$
(6) $2 \lambda \geqq \max _{i, j}\left[\sum_{\nu=1}^{m}\left(\left|a_{\nu i}\right|^{2}+\left|a_{\nu j}\right|^{2}\right)+\left\{\left[\sum_{\nu=1}^{m}\left(\left|a_{\nu i}\right|^{2}-\left|a_{\nu j}\right|^{2}\right)\right]^{2}+4\left|\sum_{\nu=1}^{m} \bar{a}_{\nu i} a_{\nu j}\right|^{2}\right\}^{1 / 2}\right]$

Proof. It was shown in [1] that the largest root of an Hermitian matrix is greater than or equal to the larger of the two roots of any principal minor of order two of the matrix. Suppose the principal minor or order two of $B$ having the largest root lies in the $r, s$ rows and columns of $B$. Then

$$
\begin{aligned}
2 \lambda & \geqq b_{r r}+b_{s s}+\left[\left(b_{r r}-b_{s s}\right)^{2}+4\left|b_{r s}\right|^{2}\right]^{1 / 2} \\
& =\sum_{\nu=1}^{n}\left(\left|a_{r \nu}\right|^{2}+\left|a_{s \nu}\right|^{2}\right)+\left\{\left[\sum_{\nu=1}^{n}\left(\left|a_{r \nu}\right|^{2}-\left|a_{s \nu}\right|^{2}\right)\right]^{2}+4\left|\sum_{\nu=1}^{n} a_{r \nu} \bar{a}_{s \nu}\right|^{2}\right\}^{1 / 2}
\end{aligned}
$$

and (3) follows. (4) is proved similarly by considering $A^{*} A$ instead of $B$.

\section{REFERENCES}

1. Alfred Brauer and A.C. Mewborn, Intervals for the characteristic roots of an Hermitian matrix, Elisha Mitchell Scien. Soc., 73 (1957), 247-254.

2. Louis Guttman, Some inequalities between latent roots and minimax (maximin) elements of real matrices, Pacific J. Math., 7 (1957), 897-902.

UNIVERSITY OF NORTh CAROLINA 


\section{PACIFIC JOURNAL OF MATHEMATICS}

\section{EDITORS}

\section{H. L. Royden}

Stanford University

Stanford, California

\section{R. A. Beaumont}

University of Washington

Seattle 5 , Washington

\author{
A. L. Whiteman
}

University of Southern California

Los Angeles 7, California

E. G. Straus

University of California

Los Angeles 24, California

\section{ASSOCIATE EDITORS}
E. F. BECKENBACH
A. HORN
L. NACHBIN
G. SZEKERES
C. E. BURGESS
V. GANAPATHY IYER
I. NIVEN
F. WOLF
M. HALL
R. D. JAMES
T. G. OSTROM
E. HEWITT
M. S. KNEBELMAN
M. M. SCHIFFER
K. YOSIDA

\section{SUPPORTING INSTITUTIONS}

\author{
UNIVERSITY OF BRITISH COLUMBIA \\ CALIFORNIA INSTITUTE OF TECHNOLOGY \\ UNIVERSITY OF CALIFORNIA \\ MONTANA STATE UNIVERSITY \\ UNIVERSITY OF NEVADA \\ OREGON STATE COLLEGE \\ UNIVERSITY OF OREGON \\ UNIVERSITY OF SOUTHERN CALIFORNIA
}

\author{
STANFORD UNIVERSITY \\ UNIVERSITY OF UTAH \\ WASHINGTON STATE COLLEGE \\ UNIVERSITY OF WASHINGTON \\ * * * * \\ AMERICAN MATHEMATICAL SOCIETY \\ CALIFORNIA RESEARCH CORPORATION \\ HUGHES AIRCRAFT COMPANY \\ THE RAMO-WOOLDRIDGE CORPORATION
}

Mathematical papers intended for publication in the Pacific Journal of Mathematics should be typewritten (double spaced), and the author should keep a complete copy. Manuscripts may be sent to any of the editors. All other communications to the editors should be addressed to the managing editor, E. G. Straus at the University of California, Los Angeles 24, California.

50 reprints per author of each article are furnished free of charge; additional copies may be obtained at cost in multiples of 50 .

The Pacific Journal of Mathematics is published quarterly, in March, June, September, and December. The price per volume (4 numbers) is $\$ 12.00$; single issues, $\$ 3.50$. Back numbers are available. Special price to individual faculty members of supporting institutions and to individual members of the American Mathematical Society: $\$ 4.00$ per volume; single issues, $\$ 1.25$.

Subscriptions, orders for back numbers, and changes of address should be sent to Pacific Journal of Mathematics, 2120 Oxford Street, Berkeley 4, California.

Printed at Kokusai Bunken Insatsusha (International Academic Printing Co., I.td.), No. 10, 1-chome, Fujimi-cho, Chiyoda-ku, Tokyo, Japan.

PUBLISHED BY PACIFIC JOURNAL OF MATHEMATICS, A NON-PROFIT CORPORATION

The Supporting Institutions listed above contribute to the cost of publication of this Journal, but they are not owners or publishers and have no responsibility for its content or policies. 


\section{Pacific Journal of Mathematics}

\section{Vol. 8, No. 2 \\ April, 1958}

John Herbert Barrett, Second order complex differential equations with a real independent variable ............................ 187

Avner Friedman, Remarks on the maximum principle for parabolic equations and its applications ......................... 201

Richard Robinson Goldberg, An inversion of the Stieltjes transform ....... 213

Olavi Hellman, On the periodicity of the solution of a certain nonlinear integral equation .................................. 219

Gilbert Helmberg, A theorem on equidistribution on compact groups...... 227

Lloyd Kenneth Jackson, Subfunctions and the Dirichlet problem ......... 243

Naoki Kimura, The structure of idempotent semigroups. I ............ 257

Stephen Kulik, A method of approximating the complex roots of equations........................................ 277

Ancel Clyde Mewborn, A note on a paper of L. Guttman.............. 283

Zeev Nehari, On the principal frequency of a membrane ............ 285

G. Pólya and I. J. Schoenberg, Remarks on de la Vallée Poussin means and convex conformal maps of the circle ...................... 295

B. M. Stewart, Asymmetry of a plane convex set with respect to its centroid .......................................... 335

Hans F. Weinberger, Lower bounds for higher eigenvalues by finite difference methods

Edwin Weiss and Neal Zierler, Locally compact division rings ......... 369

Bertram Yood, Homomorphisms on normed algebras ................. 373 